\title{
Autotrophic picoplankton dynamics in a Chesapeake Bay sub-estuary
}

\author{
Robert T. Ray*, Leonard W. Haas, Michael E. Sieracki \\ College of William and Mary, School of Marine Science, Virginia Institute of Marine Science, Gloucester Point, Virginia 23062, \\ USA
}

\begin{abstract}
The contribution of picoplankton $(0.2$ to $3.0 \mu \mathrm{m})$ to phytoplankton biomass and production was examined in a tributary of the Chesapeake Bay, USA, during summer 1985. The water column in this tributary oscillates with the spring-neap tidal cycle (homogeneously mixed and stratified, respectively) which permits observation of the effects of water column stability on phytoplankton dynamics. Picoplankton made up $7 \%$ of the seasonal autotrophic biomass, with a peak contribution of 10 to $14 \%$ in the first half of July. Phycocyanin-rich chroococcoid cyanobacteria, visible only with fluorescence microscopy using green light excitation $(510$ to $560 \mathrm{~nm})$, numerically dominated the picophytoplankton, being $8 \times$ more abundant than the phycoerythrin-containing cyanobacteria. Together these 2 cyanobacteria types represented $51 \%$ of the picophytoplankton biomass, and exhibited a pronounced fortnightly cycle in abundance which coincided with the spring-neap tidal cycle. Picoplankton were responsible for $9 \%$ of the primary production at $293 \mu \mathrm{E} \mathrm{m}^{-2} \mathrm{~s}^{-1}$ and $13 \%$ at 28 to $43 \mu \mathrm{E} \mathrm{m}^{-2} \mathrm{~s}^{-1}$, averaged over the study period. Chlorophyll-specific uptake rates by the larger autotrophs (seasonal mean, $5.2 \mu \mathrm{g} \mathrm{C} \mu \mathrm{g}$ chl $a^{-1} h^{-1}$ ) were significantly higher than the picoplankton (seasonal mean, $2.5 \mu \mathrm{g} \mathrm{C} \mu \mathrm{g} \mathrm{chl} a^{-1} \mathrm{~h}^{-1}$ ) at $293 \mu \mathrm{E} \mathrm{m}^{-2} \mathrm{~s}^{-1}$, but not at 28 to $43 \mu \mathrm{E} \mathrm{m}^{-2} \mathrm{~s}^{-1}$. A simple model based on spring-neap, tidally-induced oscillations in mixed layer depth, and its regulation of light availability, produced cycles in cyanobacterial growth rates which could partially explain the observed cycles in abundance. These results emphasize the importance of physical processes occurring on time scales of days or weeks in regulating plankton biomass and primary production in estuarine environments.
\end{abstract}

\section{INTRODUCTION}

Although oceanic autotrophic picoplankton $(0.2$ to $3.0 \mathrm{~mm}$ photoautotrophs) are recognized as major contributors to primary production (Johnson \& Sieburth 1979, Li et al. 1983, Itturiaga \& Mitchell 1986), their significance in temperate estuaries has not been established. Past studies in the Chesapeake Bay, USA, have demonstrated the substantial importance of 'nanoplankton' $\quad<20 \mu \mathrm{m}$ and often including picoplankton) in primary production, especially in late spring, summer and early fall (McCarthy et al. 1974, Van Valkenberg \& Flemmer 1974, Haas 1975, Sellner 1983). In more recent studies Synechococcus picoplankton have been observed in Atlantic coast estuaries (Johnson \& Sieburth 1979, Waterbury et al. 1979, Perkins et al. 1981, Campbell et al. 1983, Marshall \& Lacouture 1986), but their contribution to

\footnotetext{
- Present address: OERS, Virginia Water Control Board, PO Box 11143, Richmond, Virginia 23230, USA
}

estuarine primary production and dynamics was not determined.

Historically, phytoplankton studies in temperate estuaries including the Chesapeake Bay have emphasized seasonal time scales (Boynton et al. 1982, Harding et al. 1985, Fisher et al. 1988). Significant changes in plankton dynamics have, however, been shown to occur over much shorter time scales in the Chesapeake Bay. For example, wind events may cause rapid oscillations in pycnocline depth on a transect normal to the main axis of the Chesapeake Bay, resulting in enhanced production of both phytoplankton and bacteria over the shallow flanks of the Bay relative to the deeper channel (Malone et al. 1986). In the major subestuaries of the lower Chesapeake Bay (the James, York, and Rappahannock Rivers) the vertical density gradient is maximal during neap tides and is minimal, often approaching vertical homogeneity, during or shortly after spring tides (Haas 1977, Hayward et al. 1982, Hayward et al. 1986). A fortnightly periodicity in phytoplankton biomass and production, associated 
with this tidally-induced cycle of stratification has been demonstrated in the lower York River (Haas 1975, Haas et al. 1981).

The objectives of this study were to characterize the estuarine picoplankton in the lower York River and assess its importance in summer phytoplankton dynamics. Sampling was frequent enough to examine the role of fortnightly oscillations in water column stratification on picoplankton processes.

\section{METHODS}

Samples for phytoplankton cell counts and biomass estimates were collected in the lower York River at the Yorktown, Virginia, Coast Guard Station pier (Fig. 1) at 2 to 3 d intervals from July through September, 1985, at slack water before ebb tide. Water was collected with either a Van Dorn bottle (1, 3 and $5 \mathrm{~m}$ depth) or a handoperated vacuum pump (12 $\mathrm{m}$ depth, $1 \mathrm{~m}$ off the bottom). Temperatures of the 1,3 and $5 \mathrm{~m}$ samples were measured to the nearest $0.05^{\circ} \mathrm{C}$ using a stem thermometer, and salinity was determined using an induction salinometer (Beckman RS-7B). Light attenuation was calculated from downwelling irradiance of photosynthetically available radiation (PAR, 400 to 700 $\mathrm{nm}$ ) measured at sub-surface, $0.5,1,2,3,4$ and $5 \mathrm{~m}$ depths with an integrating photometer and a submersible cosine sensor (Li-Cor, model LI-188).

Equal volumes of water from 1,3 and $5 \mathrm{~m}$ were combined into a composite surface sample which was partitioned into 3 size fractions: total (unfiltered), < 15 $\mu \mathrm{m}$ (gravity-filtered through $15 \mu \mathrm{m}$ Nitex), and $<3 \mu \mathrm{m}$ (filtered through a $3 \mu \mathrm{m}$ Nuclepore filter, vacuum $<10$ $\mathrm{cm} \mathrm{Hg}$ ). For cell counts and chlorophyll, the 3 to $15 \mu \mathrm{m}$ size fraction was determined by subtracting the $<3 \mu \mathrm{m}$ from the $<15 \mu \mathrm{m}$ fraction.

Chlorophyll a was measured by filtering $5 \mathrm{ml}$ of sample through a Whatman GF/F filter (25 mm) which was immediately placed in a light-proof, capped $10 \mathrm{ml}$ vial containing $8 \mathrm{ml}$ of extraction fluid ( $45 \%$ dimethyl sulfoxide, $45 \%$ acetone, $10 \%$ distilled water, with $0.1 \%$ diethylamine; Webb \& Hayward unpubl.). After extraction in the dark at room temperature for $5 \mathrm{~d}$, chlorophyll a was determined on a Turner Designs fluorometer, calibrated with a Cary 15 scanning spectrophotometer using a chlorophyll a standard (spinach, Sigma Scientific Co.) and the trichromatic equations of Jeffrey \& Humphrey (1975).

Plankton identification and enumeration were performed by epifluorescence microscopy using the fluorochrome proflavine (Haas 1982). Counts were made using a Zeiss standard microscope equipped with a $50 \mathrm{~W}$ high pressure mercury lamp, $10 \times$ calibrated ocular, $100 \times$ plan apochromat objective and 2 epi-

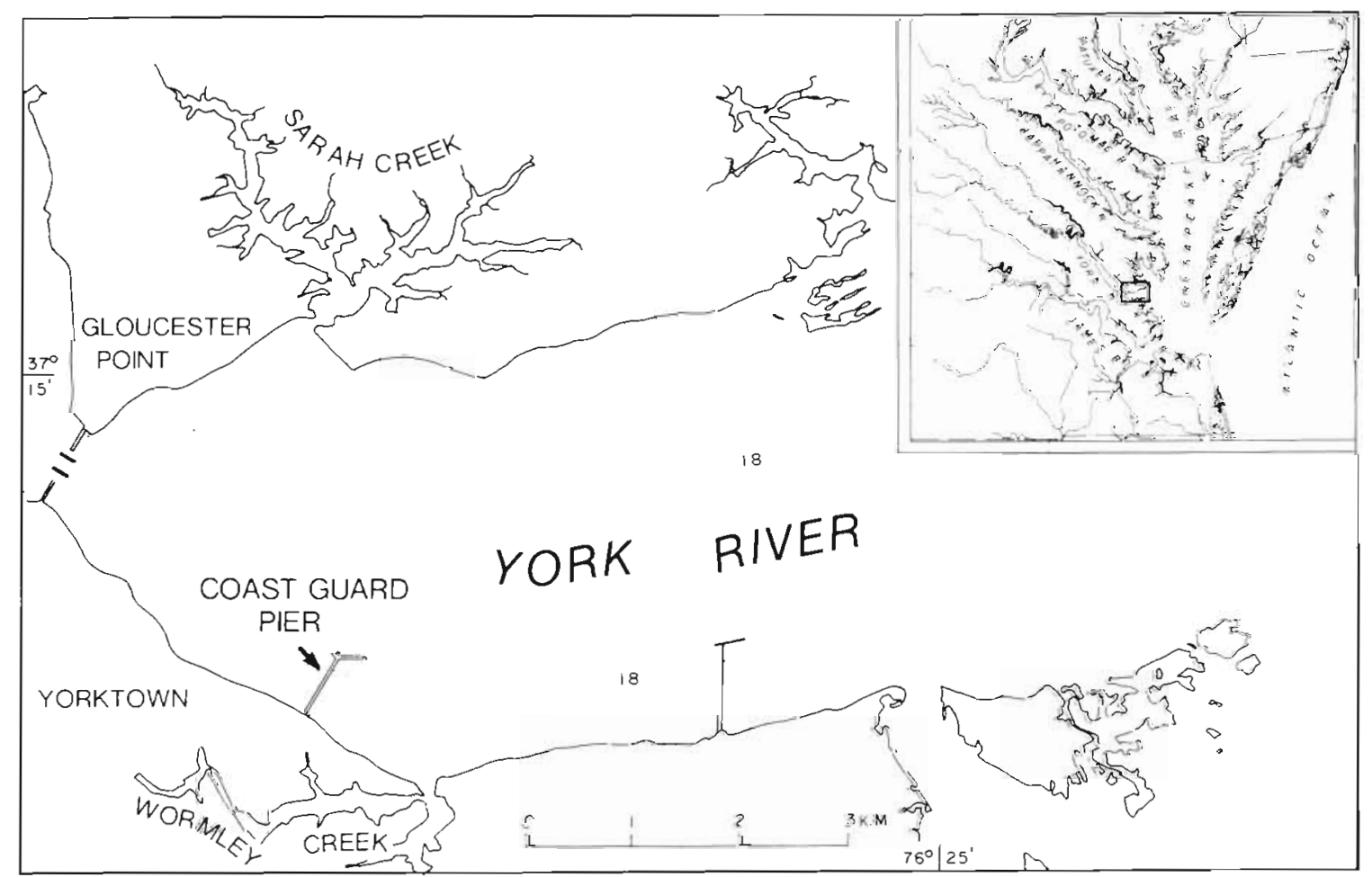

Fig. 1. Location of sampling station: Yorktown Coast Guard Pier (YCP), York River, Virginia, USA $\left(37^{\circ}, 13^{\prime} \mathrm{N}^{\prime} ; 6^{\circ}, 29^{\prime}\right.$ W) 
fluorescence filter sets. Blue excitation (450 to $490 \mathrm{~nm}$; Zeiss \#487709) was used to observe and differentiate heterotrophic from autotrophic cells on the basis of the absence or presence, respectively, of autofluorescence, and to count phycoerythrin-containing (PE) cyanobacteria which autofluoresce a gold-orange color. Since phyctocyanin-dominant (PC) cyanobacteria are not readily visible under blue light excitation (Wood et al. 1985, Waterbury et al. 1986), green excitation (510 to $560 \mathrm{~nm}$; Zeiss \#487714) was used to count PE and PC cyanobacteria. Both pigment-types of these cyanobacteria fluoresce brightly under green excitation. PC cyanobacteria abundance was then determined by subtracting PE from total cyanobacterial counts. Six categories of plankton were used in biomass estimates: PC cyanobacteria, PE cyanobacteria, diatoms, autotrophic flagellates, autotrophic dinoflagellates, and other autotrophs. Other autotrophs included all autofluorescing cells not possessing recognizable flagella, frustules, or theca. Biomass estimates were made using mean cell volume calculations of at least 100 randomly selected cells of each type and literature values of carbon: volume ratios (Sournia 1978) (Table 1).

Primary production was measured for the surface (1,3 and $5 \mathrm{~m}$ composite) total and $<3 \mu \mathrm{m}$ samples weekly using the ${ }^{14} \mathrm{C}$ technique. Water for ${ }^{14} \mathrm{C}$ experiments was collected between 05:30 and 06:30 h, and incubations begun between $07: 30$ and $08: 30 \mathrm{~h}$ to minimize diel effects on $\mathrm{C}$ uptake that would have occurred if sample collection had not been normalized to time of day. Chlorophyll a and biomass were also measured as previously described. Prior to incubation the total fraction was filtered through a $73 \mu \mathrm{m}$ Nitex sieve to remove larger grazers. Duplicate samples were placed in glass liquid scintillation vials (ca $23 \mathrm{ml}$ ) and $\mathrm{NaH}^{14} \mathrm{CO}_{3}$ (ICN) was added to a final concentration of $0.087 \mu \mathrm{Ci} \mathrm{ml}^{-1}$. Vials were incubated at in situ temperature under 4 light intensities (Duratest Ultrahigh Output Vita Lights, attenuated with neutral density screening). Light intensities in the incubator compartments were $293,54,43$, and $28 \mu \mathrm{E} \mathrm{m}^{-2} \mathrm{~s}^{-1}$. After a $4 \mathrm{~h}$ incubation period, $5 \mathrm{ml}$ of sample was withdrawn and $4 \mathrm{ml}$ of methanol:glacial acetic acid $(95: 5 \mathrm{v} / \mathrm{v})$ was added to the vials which were agitated and then placed in a drying oven at $60^{\circ} \mathrm{C}$. The sample was evaporated to dryness and the residual material was resuspended in $10 \mathrm{ml}$ of distilled water and $10 \mathrm{ml}$ of Aquasol-2. After $36 \mathrm{~h}$ the ${ }^{14} \mathrm{C}$ activity was measured in a Beckman LS 150 liquid scintillation counter. Control vials were incubated in the dark at the same temperature and dark counts were subtracted from the illuminated sample counts. The mean coefficient of variation for replicate uptake values over all days and treatments was $6.6 \%$. Production rates were calculated on the basis of sample volume, chlorophyll $a$, and carbon.

\section{RESULTS}

\section{Hydrography}

Surface temperature and salinity at the York River station ranged from 23 to $28.6^{\circ} \mathrm{C}$ and 19.5 to $23.7 \mathrm{ppt}$ respectively (Fig. 2a). For most of the observation period temperatures exceeded $25.5^{\circ} \mathrm{C}$ and salinities
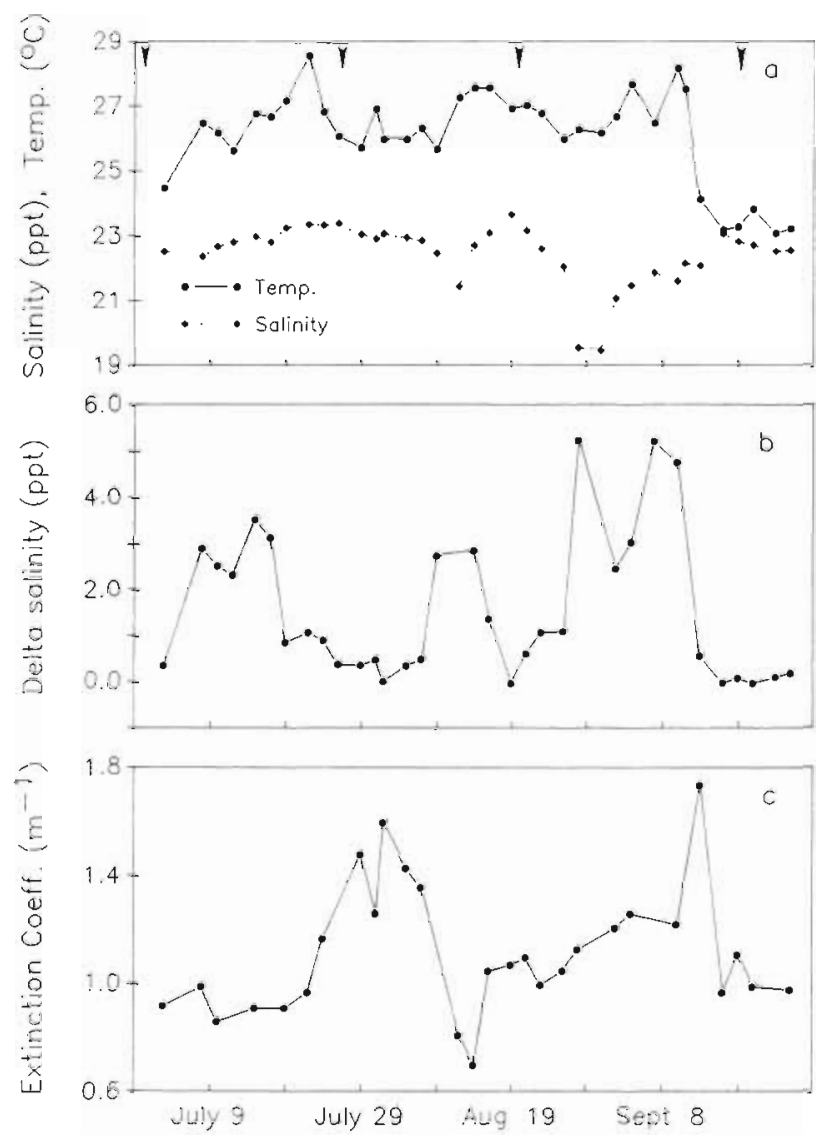

Fig. 2. Hydrographic parameters at the York River station during the time course of this study (1985). (a) Temperature ( $\bullet$ and salinity ( $\bullet$ ). (b) Surface to bottom salinity difference (delta salinity). (c) Light extinction coefficient. Arrows in (a) indicate the date of highest monthly tidal height as determined from NOAA Tide Tables (1985)

exceeded $22 \mathrm{ppt}$. The surface to bottom salinity difference (delta salinity) was used as a measure of the magnitude of the vertical density stratification and values ranged from 0 to $5.45 \mathrm{ppt}$ (Fig. 2b). This study spanned 3 monthly lunar tidal cycles with major monthly spring tides occurring on July 3 and 26 , August 21 and September 18. Consistent with previous observations on the lower York River (Haas 1977, Hayward et al. 1986), maximum stratification was observed during neap tides and minimum stratification occurred during spring tides. Extinction coefficients of PAR averaged 1.1 and ranged from 0.9 to 
$1.7 \mathrm{~m}^{-1}$ (Fig. 2c) with no apparent relationship to the magnitude of vertical density stratification.

\section{Chlorophyll $a$ and autotrophic biomass}

During the study, chlorophyll $a$ in the surface water averaged $14.2 \mu \mathrm{g} \mathrm{I}^{-1}$, with an average of $44 \%$ in the $>15 \mu \mathrm{m}$ fraction, $41 \%$ in the 3 to $15 \mu \mathrm{m}$ fraction and $15 \%$ in the $<3 \mu \mathrm{m}$ fraction (Fig. 3a). During the period August 26 to September 13 , the 3 to $15 \mu \mathrm{m}$ fraction
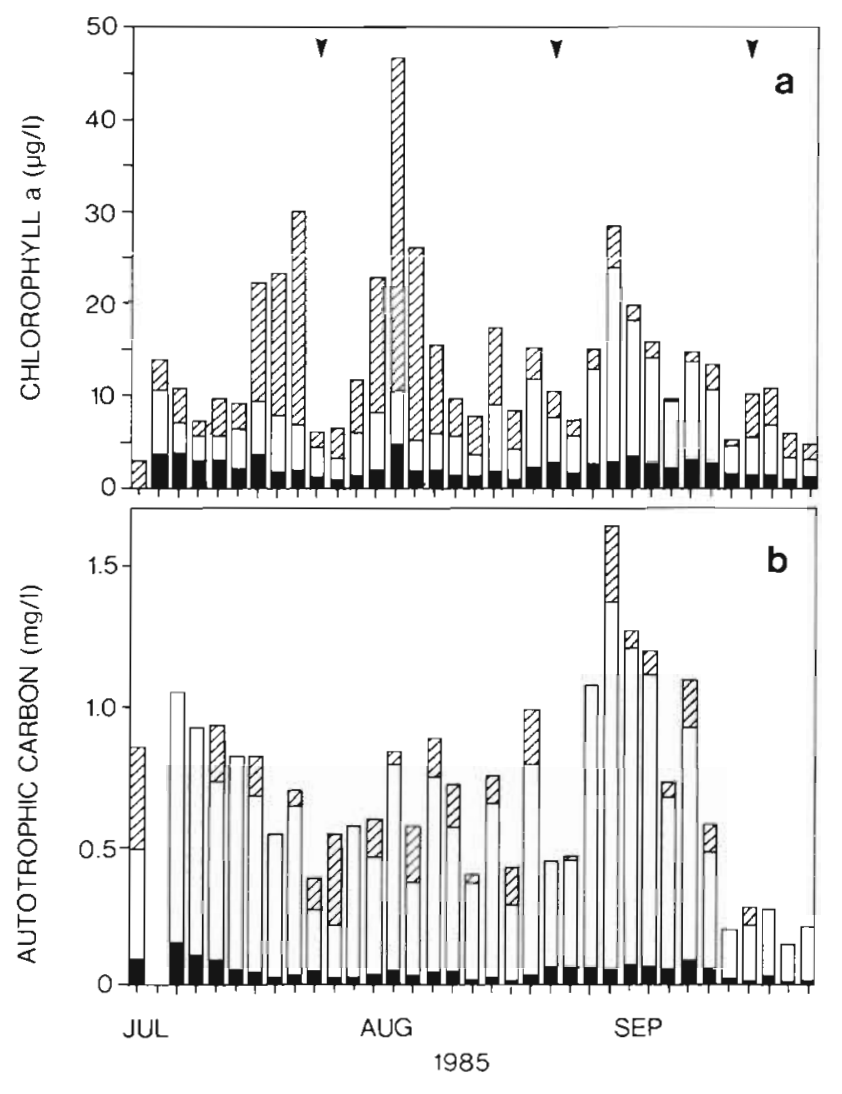

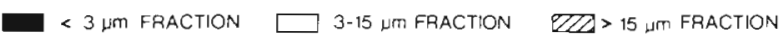

Fig. 3. Summer 1985 chlorophyll a (a) and estimated autotrophic carbon (b) in 3 size fractions at the York River station. Arrows at top as in Fig. 2

accounted for more than $60 \%$ of the total chlorophyll $a$. The $<3 \mu \mathrm{m}$ fraction contained more than $20 \%$ of the total chlorophyll a during 3 periods: July 8 to 17 , August 23 to 26, and September 10 to 16 . Two of the 3 chlorophyll peaks (August 5 and September 2) occurred subsequent to monthly spring tides.

Autotrophic biomass ranged from 140 to $1640 \mu \mathrm{g}$ $\mathrm{C}^{-1}$ (Fig. 3b) and the mean biomasses of the $>15 \mu \mathrm{m}$, 3 to $15 \mu \mathrm{m}$ and $<3 \mu \mathrm{m}$ size fractions were 78,553 , and $42 \mu \mathrm{g} \mathrm{Cl} \mathrm{I}^{-1}(12 \%, 81 \%$, and $7 \%)$, respectively (Table 1). Picoplankton accounted for 3 to $14 \%$ of the total autotrophic biomass and cyanobacteria (PC and PE) made up ca $51 \%$ of the autotrophic picoplankton biomass. The mean carbon: chlorophyll a (C:chl) ratios for the total and $<3 \mu \mathrm{m}$ fractions were $47(48.5 \%$ coefficient of variation, CV) and $20(40.2 \% \mathrm{CV})$ respectively. The Rank Sum non-parametric test indicated a significant difference $(p<0.05)$ between $C$ : chl ratios for these 2 size fractions. Total autotrophic biomass correlated well with total chlorophyll a $\left(r^{2}=0.77\right)$, while the 3 to $15 \mu \mathrm{m}$ and $<3 \mu \mathrm{m}$ fraction showed lesser correlation with their respective chlorophyll abundances $\left(r^{2}=0.58\right.$ and 0.47 , respectively).

\section{Size fractions and autotrophic numbers}

Total cyanobacteria ( $P C$ and $P E$ ) for all 3 size fractions averaged 275800 cells $\mathrm{ml}^{-1}$ and were composed entirely of coccoid forms $2 \mu \mathrm{m}$ or less in diameter. The mean PC cyanobacterial abundance exceeded that of PE cyanobacteria 8-fold. The PC cyanobacteria demonstrated 3 distinct peaks of abundance (July 8 to 17 , August 9 to 12 and August 28 to September 13) all of which coincided with periods of enhanced water column stratification (Fig. 4). PC cyanobacterial abundances were positively correlated with delta salinity $\left(r^{2}=\right.$ $0.42, p<0.001$ ) and negatively correlated with mean
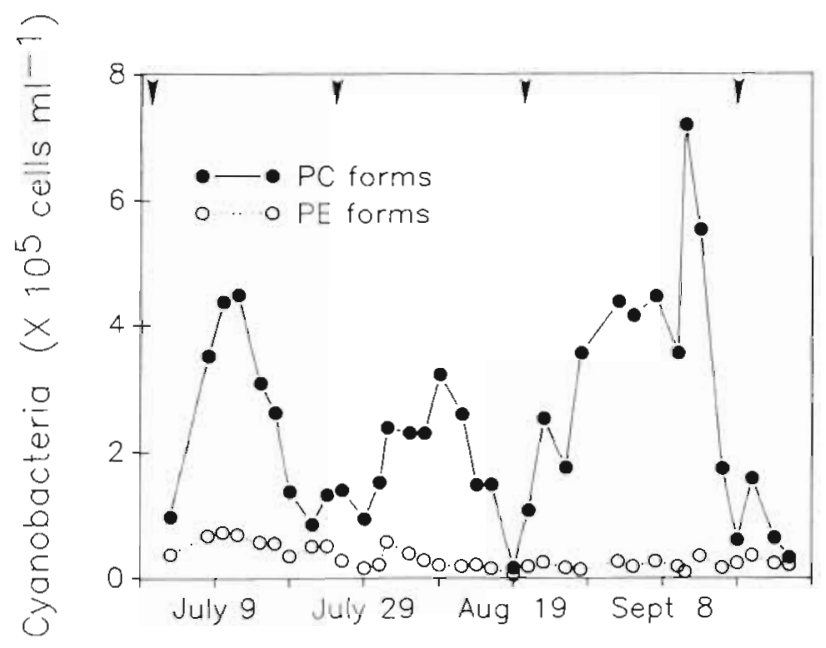

Fig. 4. Phycocyanin-dominant $(\bullet)$ and phycoerythrin-containing (o) chroococcoid cyanobacterial abundances in surface samples (total counts). Arrows at top as in Fig. 2

surface salinity $\left(r^{2}=-0.32, p<0.001\right)$. PE cyanobacterial abundance was greatest early in the study (July 8 to 24) and generally decreased thereafter (Fig. 4). Although 3 of the PE cyanobacterial temporal minima were coincident with PC cyanobacterial minima (July 3, 29, August 19), PE cyanobacterial abundance was correlated with neither delta salinity nor mean surface salinity $\left(r^{2}<0.05\right)$. 
Table 1. Summer seasonal abundances and carbon biomass values for 3 phytoplankton size fractions in the surface waters of the lower York River, 1985

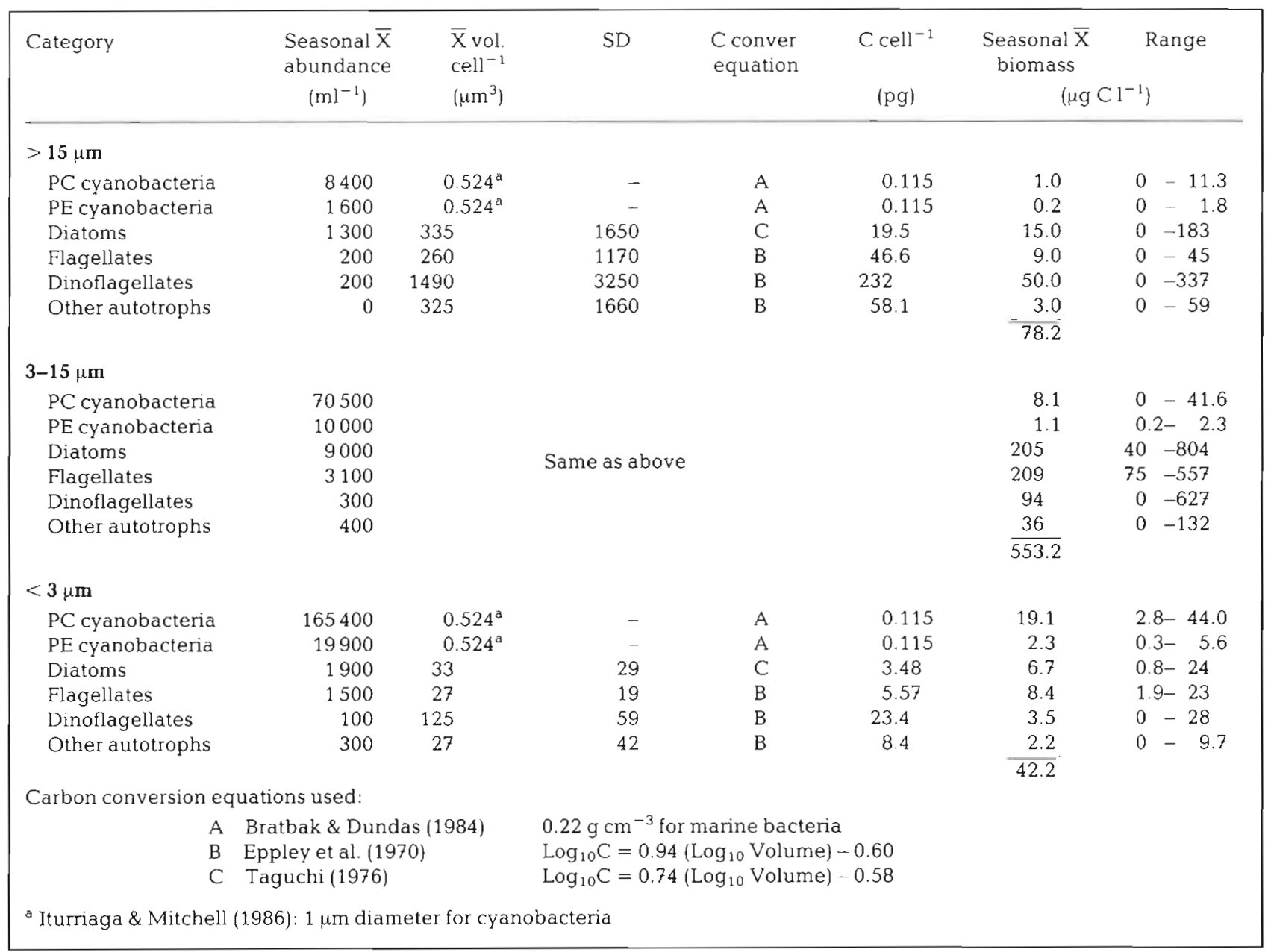

Coccoid cyanobacteria dominated the $<3 \mu \mathrm{m}$ fraction, averaging 185300 cells $\mathrm{ml}^{-1}$ (51\% of carbon biomass) compared to an average of 3800 cells $\mathrm{ml}^{-1}$ for eukaryotic picophytoplankton (Table 1). Results indicate that $33 \%$ of the total cyanobacteria were in the $>3 \mu \mathrm{m}$ size fraction. This was unexpected since a vast majority of these cells were composed of single or double cells and, based on their size, should be considered picoplankton. Adding the cyanobacteria in the $>3 \mu \mathrm{m}$ fractions to both total picophytoplankton carbon and cyanobacteria in the picoplankton increases the contribution of cyanobacteria to $60 \%$ of 'corrected' picophytoplankton cell carbon. On average only $4 \%$ of the cyanobacteria were retained on the $15 \mu \mathrm{m}$ Nitex screen and we assume this represents primarily incidental retention of very rare, large clumps of coccoid forms.

Approximately $75 \%$ and $14 \%$ of the diatoms were contained in the 3 to $15 \mu \mathrm{m}$ and $<3 \mu \mathrm{m}$ size fractions, respectively, and diatoms accounted for $37 \%$ and $14 \%$ of the cell carbon in the 3 to $15 \mu \mathrm{m}$ and $<3 \mu \mathrm{m}$ size fractions (Table 1). Diatom abundance displayed 4 temporal minima, coincident with spring tides (Fig. 5a). A pronounced peak of abundance $\left(>40000 \mathrm{ml}^{-1}\right)$ occurred during the last stratified period in late August through mid-September. Diatoms were positively correlated with a delta salinity $\left(r^{2}=0.40, p<0.001\right)$.

Of the autotrophic flagellates, $65 \%$ were observed in the 3 to $15 \mu \mathrm{m}$ fraction and included Chrysophytes, Cryptophytes, Euglenophytes, Prasinophytes and Prymnesiophytes (Table 1 ). The $<3 \mu \mathrm{m}$ size fraction contained $31 \%$ of the autotrophic flagellates but were not taxonomically distinguishable. Autotrophic flagellates accounted for $37 \%$ and $17 \%$ of the cell carbon in the 3 to 15 and $<3 \mu \mathrm{m}$ fractions, respectively. Although the maximum abundance of autotrophic flagellates occurred during the third period of stratification (i.e. coincident with the diatom maximum) there was no consistent relationship of autotrophic 

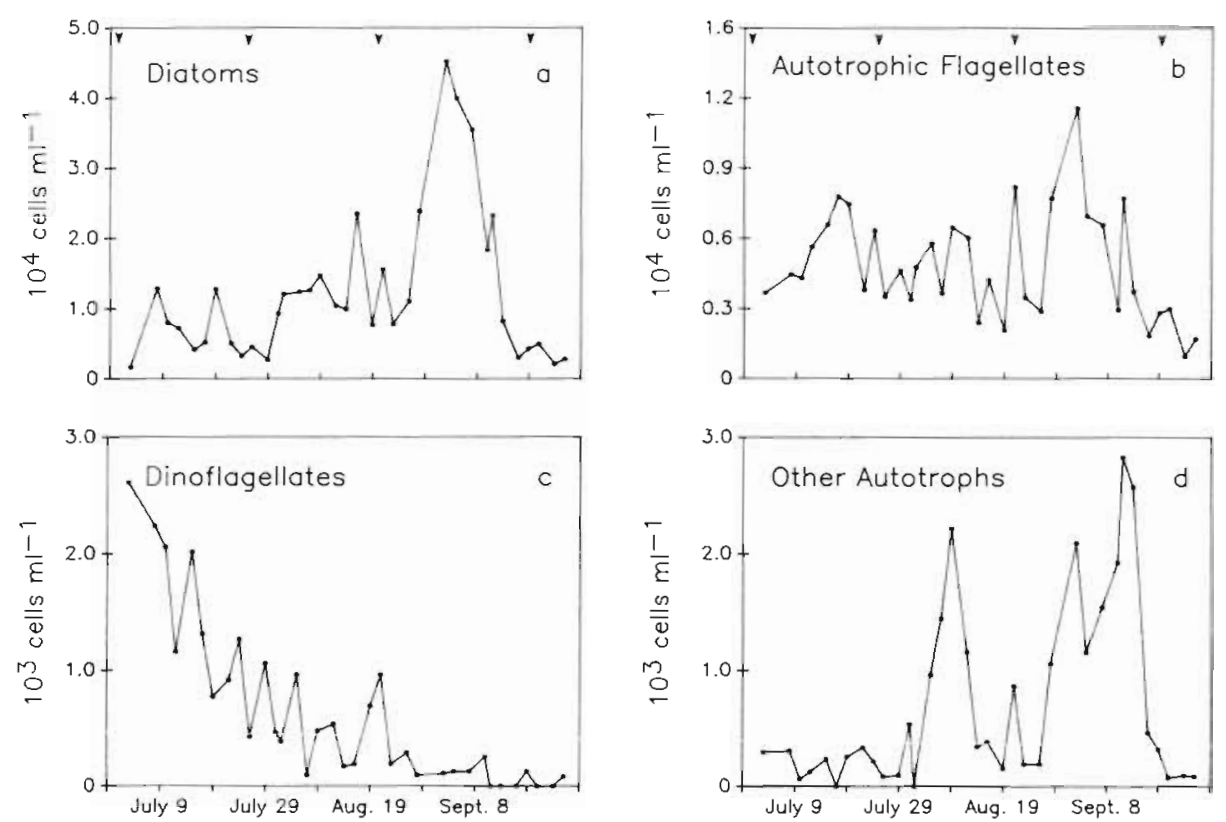

Fig. 5. Summer autotrophic abundances in surface samples (total counts). (a) Diatoms, (b) flagellates, (c) dinoflagellates, and (d) other autotrophs. Arrows at top as in Fig. 2

flagellate abundance and the stratification-destratification cycle (Fig. 5b).

Dinoflagellates occurred primarily in the 3 to $15 \mu \mathrm{m}$ and $>15 \mu \mathrm{m}$ size fractions $(50 \%$ and $33 \%$ of total dinoflagellate cells respectively), and accounted for the majority of cell carbon in the $>15 \mu \mathrm{m}$ fraction $(64 \%)$ (Table 1). The dinoflagellate contribution to the 3 to $15 \mu \mathrm{m}$ fraction cell carbon was $17 \%$. Dinoflagellates occurred abundantly in the $<3 \mu \mathrm{m}$ size fraction in July (up to $1200 \mathrm{ml}^{-1}$ ), but only rarely thereafter. The greatest densities of autotrophic dinoflagellates were observed at the beginning of the study and generally declined during the first half of the study (Fig. 5c). This decline of dinoflagellate abundance coinciding with the increase in diatom abundance is consistent with previous observations in the York River (Patten et al. 1963). Dinoflagellate abundance did not significantly correlate with delta salinity $\left(r^{2}=0.01, p<0.62\right)$.

The category 'other autotrophs' was mainly composed of the class Chlorophyceae, including Ulothrix, Scenedesmus, a small unicellular coccoid Chlorophyte, and a large colonial Chlorophyte for possibly Haptophyte) 10 to $40 \mu \mathrm{m}$ in diameter. This category displayed 2 peaks in abundance (Fig. 5 d), the first occurring August 7 to 12 and the second occurring August 28 to September 13. 'Other autotrophs' were not correlated to water column stratification $\left(r^{2}=0.14, p<0.09\right)$.

\section{Primary productivity}

Carbon uptake showed 2 major peaks for both size fractions (early August and early September) with tem- poral minima coinciding with periods of spring tide destratification (Fig. 6a). Uptake of carbon by the phytoplankton was significantly different (ANOVA, $p$ $<0.05$ ), with 3 -way interactions between size fractions, days and light intensities. The contribution of the $<3 \mu \mathrm{m}$ fraction to carbon uptake ranged from ca 5 to $17 \%$ and was inversely related to light intensity (Krus-
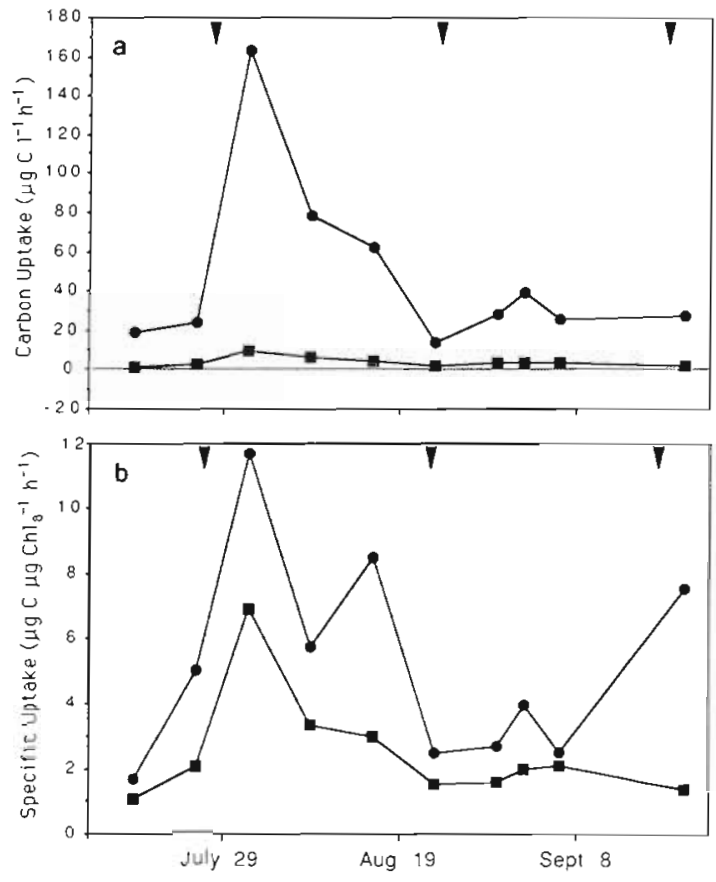

Fig. 6. Photosynthetic carbon uptake by the $>3 \mu \mathrm{m}$ fraction $(\bullet)$ and the $<3 \mu \mathrm{m}$ fraction (-) at $293 \mu \mathrm{E} \mathrm{m}^{-2} \mathrm{~s}^{-1}$ ( $\mathrm{P}_{\text {max }}$ ). (a) Carbon uptake. (b) Chlorophyll a-specific uptake 
kal-Wallace non-parametric test for significance between means, $p<0.05$; Fig. 7). At $293 \mu \mathrm{E} \mathrm{m}^{-2} \mathrm{~s}^{-1}$ (ca $15 \%$ of summer noon surface irradiance) picoplankton accounted for ca $9 \%$ of the carbon uptake, while at the 3 lower light levels (28 to $54 \mu \mathrm{E} \mathrm{m}^{-2} \mathrm{~s}^{-1}$, or 1 to $2 \%$ noon

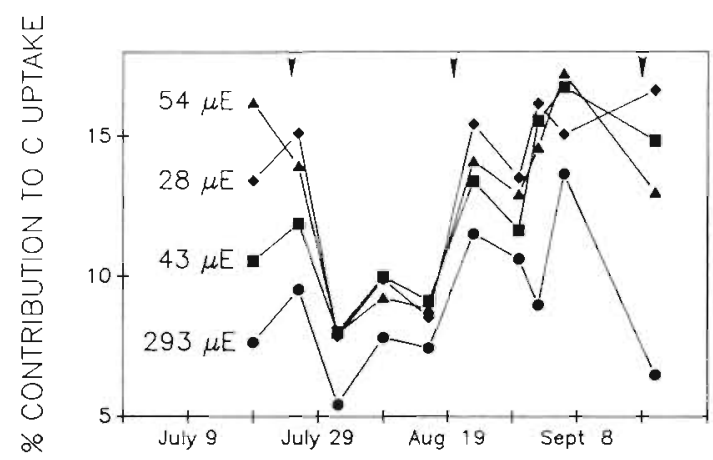

Fig. 7 Percent contribution to total photosynthetic carbon uptake by the $<3 \mu \mathrm{m}$ fraction

surface irradiance) they accounted for $13 \%$ of the carbon uptake averaged over the season (Fig. 7). At all light levels the contribution of the $<3 \mu \mathrm{m}$ fraction was minimal at the peak in primary production on August 2 and tended to be greatest in late August and early September. The contribution of the picophytoplankton was significantly less at the highest light intensity than at the 3 lower light levels (Wilcoxon Rank Sum Test, $p<0.05$ )

Chlorophyll-specific carbon uptake at the highest light intensity $\left(293 \mu \mathrm{E} \mathrm{m} \mathrm{m}^{-2} \mathrm{~s}^{-1}\right)$ for both fractions is shown in Fig. 6b. For the purposes of this study, this light level is considered saturating (see 'Discussion') and therefore these chlorophyll-specific carbon uptake rates are assimilation values $\left(\mathrm{P}_{\max }\right)$. Values of $\mathrm{P}_{\max }$ ranged from 1 to 12 and averaged 5.2 and $2.5 \mu \mathrm{g} \mathrm{C} \mu \mathrm{g} \mathrm{chl} \mathrm{a}^{-1} \mathrm{~h}^{-1}$ for the $>3 \mu \mathrm{m}$ and $<3 \mu \mathrm{m}$ fractions, respectively. $\mathrm{P}_{\max }$ for the $<3 \mu \mathrm{m}$ size fraction showed a single temporal peak on August 2, a pattern that was repeated by the uptake rates at the 3 lower light intensities. $P_{\max }$ for the larger size fraction showed 3 temporal peaks occurring on August 2, August 17 and September 20.

Carbon-specific production rates (growth rates) were calculated from carbon uptake rates and carbon biomass estimates for the $>3 \mu \mathrm{m}$ and $<3 \mu \mathrm{m}$ size fractions assuming constant carbon uptake over a $12 \mathrm{~h}$ photoperiod. Carbon-specific growth rates at $293 \mu \mathrm{E} \mathrm{m}^{-2} \mathrm{~s}^{-1}$ were greater for the picoplankton than for the larger phytoplankton in 8 of the 10 experiments (Table 2). At the 3 lower light intensities the growth rate for the $<3 \mu \mathrm{m}$ autotrophs always exceeded the $>3 \mu \mathrm{m}$ autotrophs, with the exception of one experiment at a single light level. Averaged over all experiments, the smaller size fraction showed significantly higher growth (Rank Sum nonparametric test, $p<0.05$ ) than the $>3 \mu \mathrm{m}$ size fraction at all light intensities, and a comparison of ratios $1<3$ $\mu \mathrm{m}:>3 \mu \mathrm{m})$ indicates that this difference increases steadily with decreasing light intensity (Table 2 ).

\section{DISCUSSION}

\section{Seasonal biomass and composition}

Despite the intense interest in the role of coccoid cyanobacteria in oceanic planktonic processes (Platt \& $\mathrm{Li}$ 1986), considerably less attention has been accorded to their role in the estuarine plankton. The period of observation in the present study was intended to encompass the time period of peak cyanobacterial abundance at this site (Perkins et al. 1981). A pronounced summer maxima of cyanobacterial abundance appears to be a characteristic feature of temperate and boreal estuaries

Table 2. Seasonal means and ranges of carbon specific growth rates $\left(\mathrm{d}^{-1}\right)$ for the greater and less than $3 \mu \mathrm{m}$ autotrophs and their ratio calculated from ${ }^{14} \mathrm{C}$ uptake rates using a $12 \mathrm{~h}$ photoperiod. Also shown are the initial slopes of the growth vs I curves (alpha,

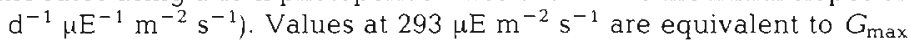

\begin{tabular}{|c|c|c|c|c|}
\hline \multirow{2}{*}{$\begin{array}{l}\text { Light intensity } \\
\left(\mu \mathrm{E} \mathrm{m}^{-2} \mathrm{~s}^{-1}\right)\end{array}$} & \multirow[t]{2}{*}{ Size fraction } & \multicolumn{3}{|c|}{ Growth rate $\left(\mathrm{d}^{-1}\right)$} \\
\hline & & Seasonal mean & Range & Ratio $(<3 />3)$ \\
\hline 28 & $\begin{array}{l}>3 \mu \mathrm{m} \\
<3 \mu \mathrm{m}\end{array}$ & $\begin{array}{l}0.299 \\
0.605\end{array}$ & $\begin{array}{l}0.078-0.717 \\
0.263-1.350\end{array}$ & 2.023 \\
\hline 43 & $\begin{array}{l}>3 \mu \mathrm{m} \\
<3 \mu \mathrm{m}\end{array}$ & $\begin{array}{l}0.454 \\
0.877\end{array}$ & $\begin{array}{l}0.118-1.051 \\
0.303-2.027\end{array}$ & 1.932 \\
\hline 54 & $\begin{array}{l}>3 \mu \mathrm{m} \\
<3 \mu \mathrm{m}\end{array}$ & $\begin{array}{l}0.551 \\
0.996\end{array}$ & $\begin{array}{l}0.091-1.308 \\
0.384-2.508\end{array}$ & 1.808 \\
\hline 293 & $\begin{array}{l}>3 \mu \mathrm{m} \\
<3 \mu \mathrm{m}\end{array}$ & $\begin{array}{l}1.016 \\
1.340\end{array}$ & $\begin{array}{l}0.259-2.694 \\
0.409-3.439\end{array}$ & 1.319 \\
\hline Alpha & $\begin{array}{l}>3 \mu \mathrm{m} \\
<3 \mu \mathrm{m}\end{array}$ & $\begin{array}{l}0.008 \\
0.013\end{array}$ & $\begin{array}{l}0.003-0.023 \\
0.004-0.038\end{array}$ & 1.625 \\
\hline
\end{tabular}


(Table 3). The mean cyanobacterial abundance in the present study $\left(2.75 \times 10^{5} \mathrm{ml}^{-1}\right)$ exceeds the summer maximum reported for most other estuaries and our observed peak cyanobacterial abundance of $7 \times 10^{5}$ $m l^{-1}$ exceeds any other reported estuarine value. Although cyanobacteria in the lower York River were the numerically dominant picophytoplankton (on average $98 \%$ ) their contribution to picophytoplankton biomass was less pronounced, accounting on average for $51 \%$ of the standing stock. The remaining picophytoplankton biomass was accounted for by eukaryotes, consistent with observations in other estuarine and coastal waters which have shown a significant contribution of eukaryotes to picoplankton biomass (Johnson \& Sieburth 1982 , Furnas 1983, Glover et al. 1985a, b, Thomsen 1986). In contrast, Jochem (1988) observed coccoid cyanobacteria to consistently comprise more than $75 \%$ of the picoplankton carbon from July through October in the Kiel Bight. However, this cyanobacterial dominance was more attributable to the large size of the dominant cyanobacteria ( $2 \mu \mathrm{m}$ spheres and $2 \times 2.5 \mu \mathrm{m}$ ellipsoids), than to high concentrations of such cells.

Unlike oceanic systems where only PE-containing cyanobacteria have been observed (Murphy \& Haugen 1985, Waterbury et al. 1986, Campbell \& Carpenter 1987, Booth 1988), the PC:PE ratio of ca 8 observed in the lower York River illustrates both the importance of PC cyanobacteria in estuarine systems and the necessity of utilizing green and blue light excitation for accurately enumerating estuarine cyanobacteria. Previous estuarine studies have either used blue light excitation only, in which case total cyanobacterial numbers are likely to be underestimated, or have used both green and blue excitation light but do not distinguish between $\mathrm{PE}$ and $\mathrm{PC}$ cyanobacteria types (Table 3). Campbell et al. (1983) observed a PC:PE ratio of ca 0.02 in the Carmans River estuary, Long Island Sound, USA. Their enumeration of PC-dominant cyanobacteria, however, was based on the immunofluorescent reaction of naturally occurring cyanobacteria to the antisera of 2 cultured PC cyanobacteria, rather than direct observation of autofluorescing $\mathrm{PC}$ cyanobacteria.

Although it is recognized that PC-dominant cyanobacteria are not observed in oceanic systems, little attention has been accorded to the effect of salinity on

Table 3. Peak summer abundances and ratios of phycocyanin to phycoerythrin types of coccoid cyanobacteria in estuaries

\begin{tabular}{|c|c|c|c|c|c|c|}
\hline Estuary & $\begin{array}{c}\text { Cyano- } \\
\text { bacteria } \\
\left(\times 10^{5} \mathrm{ml}^{-1}\right)\end{array}$ & $\begin{array}{l}\text { Excitation } \\
\text { filter }^{a}\end{array}$ & $\mathrm{PC} / \mathrm{PE}^{\mathrm{b}}$ & $\begin{array}{l}\text { Salinity } \\
\text { (ppt) }\end{array}$ & $\begin{array}{l}\text { Temp. } \\
\left({ }^{\circ} \mathrm{C}\right)\end{array}$ & Source \\
\hline $\begin{array}{l}\text { Woods Hole Harbor, MA, USA } \\
\text { (8 yr) }\end{array}$ & $0.9-1.1$ & $B, G$ & No $P^{C}$ & $32^{c}$ & $20-22.5$ & Waterbury et al. (1986) \\
\hline Boothbay Harbor, ME, USA & 1.6 & $\mathrm{~B}, \mathrm{G}$ & NR & $28-32$ & $14-17$ & Shapiro \& Haugen (1988) \\
\hline $\begin{array}{l}\text { Menai Straits, Wales, UK } \\
(2 \mathrm{yr})\end{array}$ & $1.3,1.5$ & B & - & NR & $16-18$ & El Hag \& Fogg (1986) \\
\hline $\begin{array}{l}\text { Kiel Fjord, FRG } \\
\text { (2 stns) }\end{array}$ & $2.0,2.6$ & NR & NR & $13-14$ & $15-17$ & Jochem (1988) \\
\hline $\begin{array}{l}\text { Gulf of Finland } \\
\text { (5 stns) }\end{array}$ & $0.5-2.6$ & B & - & $4-6$ & $12-13$ & Kuosa (1988) \\
\hline \multicolumn{7}{|l|}{ Great South Bay, Long I., USA } \\
\hline Carmans Rivere (3 stns) & $1.4-3.4$ & $\begin{array}{l}\mathrm{B}, \mathrm{PC} \\
\text { antisera }\end{array}$ & 0.02 & NR & NR & Campbell et al. (1983) \\
\hline Carmans River & 5 & $B, G$ & NR & NR & 26 & Campbell \& Carpenter (1987) \\
\hline \multicolumn{7}{|l|}{ Long Island Sound, USA } \\
\hline Crane Neck & 1.9 & $B, G$ & NR & NR & 24 & Campbell \& Carpenter (1987) \\
\hline Crane Neck & 2.3 & NR & NR & $25-28$ & 24 & Carpenter \& CampbeIl (1988) \\
\hline \multicolumn{7}{|l|}{ Chesapeake Bay, USA } \\
\hline Lower York River & 0.6 & B & - & NR & NR & Perkins et al. (1981) \\
\hline Lower Bay & 3.5 & B & - & NR & NR & Perkins et al. (1981) \\
\hline Lower York River & $\begin{array}{l}2.7(\bar{x}) \\
7.2 \text { (peak) }\end{array}$ & $B, G$ & 8 & $19-24$ & $23-29$ & This study \\
\hline 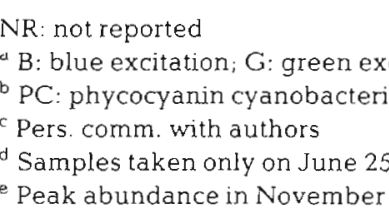 & $\begin{array}{l}\text { citation } \\
\text { a) PE: phycoer } \\
\text { and } 26,1987\end{array}$ & rtythrin cya & bacteria & & & \\
\hline
\end{tabular}


the distribution of chroococcoid cyanobacteria. Waterbury et al. (1986) report that PE-containing cyanobacteria have an obligate requirement for elevated concentrations of ions while marine Synechococcus isolates that lack PE are halotolerant and grow equally well in seawater or freshwater. The significant negative correlation observed between PC-dominant cyanobacteria and mean surface salinity is consistent with our observation of an increasing PC:PE ratio progressing upriver during August in the nearby James River estuary with no PE-containing cyanobacteria observed below 10 ppt (Haas \& Pearl 1988) and the absence of PC-dominant cyanobacteria in oceanic systems. In the present study, mean monthly surface salinities were 2 to $4 \mathrm{ppt}$ higher than the $25 \mathrm{yr}$ mean (Wojcik 1981) which may have reduced the PC:PE ratio at the site.

The contribution of picoplankton to total phytoplankton biomass consistently exceeds $50 \%$ in the tropical Atlantic (Herbland et al. 1985) and in temperate coastal waters off Japan the picoplankton contribution ranged from 5 to $47 \%$ (Takahashi et al. 1985). Similarly, in those instances in which picoplankton dominate primary production (e.g. $>50 \%$; Platt et al. 1983, Takahashi \& Bienfang 1983) one may also expect a corollary picoplankton dominance of biomass. The picoplankton contribution to estuarine phytoplankton standing stock appears to be less pronounced than in many oceanic systems. In the present study, picophytoplankton biomass ranged from 7.7 to $126.0 \mu \mathrm{g} \mathrm{Cl}^{-1}$ and accounted, on average, for $7 \%$ of the autotrophic biomass, with a peak contribution (10 to $14 \%$ ) in early July. Furnas (1983) observed that picophytoplankton (in this instance $<5 \mu \mathrm{m}$ ) carbon was generally less than $250 \mu \mathrm{g}$ $\mathrm{Cl}^{-1}$ (excluding a peak of ca $1350 \mu \mathrm{g} \mathrm{Cl}^{-1}$ in early June) and averaged $29 \%$ of the total summer chlorophyll in Narragansett Bay $(55 \%$ over the first half of the summer). In Kiel Bight and Kiel Fjord the picoplankton $(<3 \mu \mathrm{m})$ contribution to total phytoplankton biomass ranged from 8 to $52 \%$ during the summer (Jochem 1988). The greatest contribution was observed in August (32 to $52 \%$ of the total) when picoplankton carbon averaged ca $120 \mu \mathrm{g} \mathrm{Cl}^{-1}$. As mentioned previously, the picoplankton contribution is enhanced by the large size of the dominant cyanobacteria.

As discussed by $\mathrm{Li}$ (1986), the derivation of carbon biomass from cell counts is very sensitive to the cellular carbon conversions used and the measurement of linear cell dimension. Volume to carbon conversions for cyanobacteria range from $86 \mathrm{fg} \mathrm{C} \mu \mathrm{m}^{-3}$ (Krempin \&

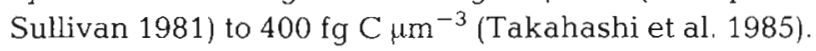
Volume-specific carbon content for bacteria is also controversial with values ranging from $121{\mathrm{fg} \mathrm{C} \mathrm{Cm}^{-3}}^{-3}$

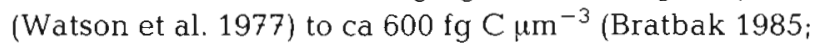
see also Bratbak \& Dundas 1984, Lee \& Fuhrman 1987).
Reported cyanobacterial cell volumes range from $0.2 \mu^{3}$ cell $^{-1}$ (Johnson \& Sieburth 1979, Sieburth 1984) to $5.23 \mu^{3}$ cell $^{-1}$ (Jochem 1988). While these differences in volume may reflect actual differences in size, slight differences in linear measurements of cells in the cyanobacterial size range can also greatly affect the cell volume (e.g. an increase in spherical diameter from 0.9 to $1.1 \mu \mathrm{m}$ will nearly double cell volume). Cellular carbon values for naturally occurring cyanobacteria range from $46 \mathrm{fg} \mathrm{C} \mathrm{cell}^{-1}$ (Krempin \& Sullivan 1981) to $700 \mathrm{fg} \mathrm{C}$ cell $^{-1}$ (Jochem 1988). The measured carbon contents of cultured Synechococcus clone WH7803 include 150 to $290 \mathrm{fg} \mathrm{C}$ cell $^{-1}$ (Waterbury et al. 1986) for cells grown in light-dark cycles and $250 \mathrm{fg} \mathrm{C}^{\mathrm{C}} \mathrm{cell}^{-1}$ (Kana \& Glibert 1987) and $294 \mathrm{fg} \mathrm{C}$ cell $^{-1}$ (Cuhel \& Waterbury 1984) for the same strain grown under continuous light. We chose to use a value for in situ Synechococcus of $115 \mathrm{fg} \mathrm{C}$ cell $^{-1}$ (calculated using $0.22 \mathrm{~g} \mathrm{C} \mathrm{cm}^{-3}$ and a $1.0 \mu \mathrm{m}$ diameter sphere). This decision was based on the observation that clone WH7803 grown under a light-dark cycle has a lower cellular carbon content $\left(210 \mathrm{fg} \mathrm{C}\right.$ cell $^{-1}$; Waterbury et al. 1986) than cells grown under continuous light and our observation that in situ forms were smaller in volume than laboratory clones WH7803 and WH8018. In addition, we wished to use conservative values, so our biomass values are minimal contribution estimates. While it might be expected that cyanobacteria would have volume-specific carbon content different from algae, our value of $115 \mathrm{fg} \mathrm{C} \mathrm{cell}^{-1}$ is only $16 \%$ less than that obtained using the Eppley et al. (1970) formula for non-diatom phytoplankton of equal size.

In the present study carbon: chlorophyll a ratios were significantly lower for the picoplankton than for the larger $(>3 \mu \mathrm{m}$ ) plankton (seasonal means of 20 and 52 respectively). It is to be expected that the $\mathrm{C}: \mathrm{chl}$ ratio will decrease with decreasing cell size (Malone 1980). Takahashi et al. (1985) observed C:chl ratios ranging from 15.5 to 79 (mean 32) for naturally occurring cyanobacteria in coastal waters off Japan. This ratio is also very sensitive to the determination of cellular carbon biomass. In Narragansett Bay, for example, Furnas (1983) observed the $\mathrm{C}$ : chl ratio for the $<5 \mu \mathrm{m}$ fraction, dominated by $5 \mu \mathrm{m}$ flagellages and $2 \mu \mathrm{m}$ non-motile spheres, was reduced from 75 to between 20 and 30 if the mean size of these 2 forms was reduced by $1 \mu \mathrm{m}$ and $0.5 \mu \mathrm{m}$ respectively. In their study of coastal California waters, Putt \& Prezelin (1985) increased the carbon content of cyanobacteria from $46 \mathrm{fg} \mathrm{C}^{-1} \mathrm{cell}^{-1}$ to $294 \mathrm{fg} \mathrm{C}$ cell $^{-1}$, since the former value resulted in abnormally low $C$ : chl ratios of 2 to 9 for the $<5.0 \mu \mathrm{m}$ fraction while the latter value yielded a $C$ : chl ratio of 50. It is apparent that accurate determination of cellular biomass is essential for assessing the contribution of picoplankton to plankton processes. 


\section{Carbon uptake}

Just as the retention of cyanobacteria by the larger size fractions reduced the biomass contribution of the $<3 \mu \mathrm{m}$ fraction, so their exclusion from the picoplankton also reduced the primary production of this size fraction. Including the cyanobacteria retained in the 2 larger size fractions in the picoplankton would be expected to increase the primary production of this size fraction on average by ca $25 \%$ (the one third of the total cyanobacteria in the larger size fraction represents ca $25 \%$ of the measured picoplankton carbon). The increase in picoplankton contribution to total primary production resulting from this repartitioning is minimal, but does serve to illustrate that our observed values for picophytoplankton production are conservative.

Based on literature values (Harding et al. 1985, Glover et al. $1985 \mathrm{a}, \mathrm{b})$, it was presumed that $293 \mu \mathrm{E}$ $\mathrm{m}^{-2} \mathrm{~s}^{-1}$ represents saturating light intensity for both fractions and that chlorophyll-specific uptake rates at this intensity represented $P_{\max }$ (Fig. 6). It was apparent that light saturation values were always above $54 \mu \mathrm{E}$ $\mathrm{m}^{-2} \mathrm{~s}^{-1}$ for both fractions, as uptake rates at $293 \mu \mathrm{E}$ $\mathrm{m}^{-2} \mathrm{~s}^{-1}$ were always greater than at $54 \mu \mathrm{E} \mathrm{m} \mathrm{m}^{-2} \mathrm{~s}^{-1}$. $P_{\max }$ values in this study (Fig. 6b: 1.66 to 11.68 for the $>3 \mu \mathrm{m}$ autotrophs and 1.05 to 6.90 for the $<3 \mu \mathrm{m}$ autotrophs) are well within values reported in the literature for natural populations of phytoplankton in the Chesapeake Bay (Haas et al. 1981, Harding et al. 1985). This study found statistically significantly lower $\mathrm{P}_{\max }$ values for the picoplankton fraction than the larger plankton and other fractionation studies have reported this same occurrence (Takahashi \& Bienfang 1983, Putt \& Prézelin 1985, Cole et al. 1986). This is a result of small cells having both a higher chlorophyll to carbon ratio and proportionately lower carbon uptake at higher light intensities than the larger cells. At lower light intensities, however, chlorophyll-specific uptake rates were not significantly different between fractions (data not shown).

While carbon-specific growth rates for the $<3 \mu \mathrm{m}$ fraction were higher at all light intensities, the ratios of the $<3 \mu \mathrm{m}$ to $>3 \mu \mathrm{m}$ growth rates were inversely proportional to light intensity (Table 3), indicating more efficient carbon uptake by the smaller cells at low light. Thus in temperate estuaries, where low mean mixed layer light intensities are common, one might expect cyanobacteria contribution to carbon uptake to exceed their contribution to biomass. Picoplankton in this study, while comprising only $7 \%$ of autotrophic biomass, contribute $13 \%$ of productivity at low light intensity

\section{Vertical mixing and picoplankton dynamics}

The strongest temporal signals we observed were peak abundances of cyanobacteria and diatoms during periods of water column stratification, and minima during periods of vertical mixing. Our observed co-occurrence of diatoms and cyanobacteria is contrary to Shapiro \& Haugen (1988), who observed a negative correlation between diatoms and cyanobacteria in Boothbay Harbor, Maine, USA. They found peak cyanobacterial abundance in late summer and mid-winter, and peak diatom abundances in spring and fall.

The close correlation between phytoplankton populations and the monthly tidal cycle observed in this study was only seen in non-motile forms (cyanobacteria, diatoms, and other autotrophs). We hypothesize that these populations are controlled by light availability for growth. Light availability is, in turn, determined by mixed layer depth which is regulated by the monthly stratification-mixing cycle. To test this hypothesis we used a simple model to calculate cyanobacterial growth rate using the averaged surface mixed layer light intensity for the days of sampling and growth rate-light relationships for the picoplankton. Mean surface mixed layer irradiance $(\overline{\mathrm{I}})$ was calculated as:

$$
\overline{\mathrm{I}}=\frac{\mathrm{I}_{0}}{k z}\left(1-\mathrm{e}^{-k z}\right)
$$

where $z=$ depth of the surface mixed layer; $k=$ the extinction coefficient; and $\mathrm{I}_{0}=$ daily incident PAR. $\mathrm{I}_{0}$ was set at 54,49 and $44 \mathrm{E} \mathrm{m}^{-2} \mathrm{~d}^{-2}$ for July, August, and September, respectively, representing average daily insolation for cloudless days. The average measured extinction coefficient, $k=1.1 \mathrm{~m}^{-1}$, was used and the depth of the mixed layer $(z)$ was determined from the delta salinity values using the model for the York River derived by Hayward et al. (1986).

Cyanobacterial growth rates $(G)$ were then calculated using a variation of the model of Jassby \& Platt (1976):

$$
G=G_{\max } \tanh \left(\frac{\alpha I}{G_{\max }}\right)
$$

where $G_{\max }=$ the growth rate at saturating light intensities; and $\alpha=$ the slope of the growth-irradiance curve in the linear portion. The model uses values of $G_{\max }$ and $\alpha$ derived experimentally from the ${ }^{14} \mathrm{C}$ uptake experiments (Table 2). The resulting predicted cyanobacterial growth rates are shown in Fig. 8 along with the observed cell concentrations. The close correlation between growth rates predicted by the model and cyanobacterial abundance supports the contention that hydrographic influences on cyanobacterial growth significantly affect their abundances. 


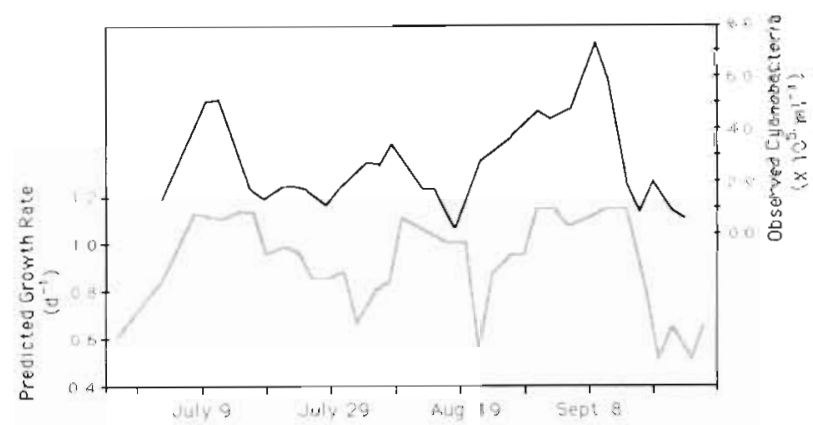

Fig. 8. Cyanobacterial abundances in the surface mixed layer, and predicted growth rates calculated from surface mixed layer depth and light-growth rate parameters measured for the $<3 \mu \mathrm{m}$ size fraction over the time period of this study

This simple model does not account for the observed decreases in cyanobacteria, which could be due to dilution during destratification or grazing exceeding growth. The process of destratification causes a dilution of the surface cyanobacteria with the bottom populations, which were always lower than the surface (Table 4). The dilution effect during the 3 observed destratification events was calculated using the hypsometry of the York River cross-section at the station, the depth of the surface mixed layer (z), and the observed surface and bottom cyanobacteria concentrations. This calculation shows that mixing alone accounted for 35 to $85 \%$ of the total decline in cyanobacteria. The loss of cells not accounted for by mixing can be interpreted as a minimum mortality rate. Our calculated rates (Table 4) match published grazing rates by heterotrophic flagellates on bacteria for the lower Chesapeake Bay (McManus \& Fuhrman 1988) based on our observed seasonal mean of $2500 \mathrm{ml}^{-1}$ (data not shown).

In summary, the nanoplankton ( 3 to $15 \mu \mathrm{m}$ ) appeared to be the dominant summer autotrophs in the York River Estuary. Over the course of the study, the auto- trophic picoplankton represented a small but measurable and possibly significant standing stock of carbon, dominated by the PC cyanobacteria. Subsequent studies of estuarine cyanobacteria must use epifluorescence microscopy and green excitation to accurately account for these cells. While photosynthetic efficiency is often considered on a chlorophyll-specific basis, when considered on a carbon-specific basis the picoplankton were significantly more efficient, especially at low light levels. The higher contribution of picoplankton to total carbon fixation at lower light intensities, however, suggests that at times of high turbidity or deeper surface mixed layer their role in primary production is greater than their biomass indicates. High productivity and relatively constant standing stock (relative to the larger cells) suggest that the $<3 \mu \mathrm{m}$ autotrophs have a significant role in the food web of the lower York River. The destratification-stratification of the water column as a consequence of the spring-neap tidal cycle plays an important role in both the standing stock and primary production of the autotrophs in the mesohaline reaches of the York River Estuary. Initial destratification or mixing of the water column decreases autotroph numbers, through physical dilution and lower growth rates due to increased surface mixed layer depth. With the onset of water column stratification, autotrophs increase in number and primary production appears to be highest early during this period as well.

Acknowledgements. R. T. Ray was employed by the Horn Point Environment Lab, University of Maryland, during the preparation of this manuscript, and thanks Pat Glibert for her helpful discussions. The authors thank John Ruzecki for the York River hypsometry data and Ken Webb, Richard Wetzel and Peter Eldridge for helpful discussions. This work was funded in part by the Oceanography section, NSF Grant OCE 81-10396. This is VIMS contribution 1499.

Table 4. Analysis of dilution due to vertical mixing on cyanobacteria populations in the surface mixed layer (SML) over the 3 periods of observed decline during 1985

\begin{tabular}{|c|c|c|c|c|c|}
\hline \multirow{2}{*}{$\begin{array}{l}\text { Decline period } \\
\text { (Julian dates) }\end{array}$} & \multicolumn{3}{|c|}{ Mean SML cells $\left(\times 10^{5} \mathrm{ml}^{-1}\right)$} & \multirow{2}{*}{$\begin{array}{c}\% \text { of decline } \\
\text { due to mixing }\end{array}$} & \multirow{2}{*}{$\begin{array}{l}\text { Rate of decline } \\
\text { not due to mixing } \\
\text { (cells } \mathrm{ml}^{-1} \mathrm{~h}^{-1} \text { ) }\end{array}$} \\
\hline & $\mathrm{S}_{\mathrm{obs}}{ }^{\mathrm{a}}$ & $M_{o b s}^{b}$ & $M_{\exp }{ }^{c}$ & & \\
\hline $193-200$ & 5.14 & 1.59 & 3.23 & 54 & 976 \\
\hline $221-226$ & 2.91 & 1.19 & 2.30 & 35 & 927 \\
\hline $253-259$ & 5.26 & 1.22 & 1.83 & 85 & 418 \\
\hline \multicolumn{6}{|c|}{$\begin{array}{l}{ }^{a} S_{\text {obs }} \text { : mean concentration observed during the stratified period before mixing } \\
{ }^{b} M_{\text {obs }} \text { : mean concentration observed during the destratified (mixed) period } \\
{ }^{c} M_{\text {exp }} \text { : expected cyanobacteria concentrations due to mixing calculated using the hypsometry of the York River cross-section } \\
\text { at the station location, SML depth, and surface and bottom cyanobacteria concentrations. Mean bottom cyanobacteria } \\
\text { concentrations during the stratified periods ranged from } 0.88 \text { to } 1.73 \times 10^{5} \mathrm{ml}^{-1} \\
{ }^{d} \text { Percent of decline due to mixing }=\frac{\mathrm{S}_{\text {obs }}-\mathrm{M}_{\text {exp }}}{\mathrm{S}_{\text {obs }}-\mathrm{M}_{\text {obs }}} \times 100\end{array}$} \\
\hline
\end{tabular}




\section{LITERATURE CITED}

Booth, B. C. (1988). Size classes and major taxonomic groups of phytoplankton at two locations in the subarctic Pacific Ocean in May and August, 1984. Mar. Biol. 97: 275-286

Boynton, W. R., Kemp, W. M., Keefe, C. W. (1982). A comparative analysis of nutrients and other factors influencing estuarine phytoplankton production. In: Kennedy, V. (ed.) Estuarine comparisons. Academic Press, New York, p. $69-90$

Bratbak, G. (1985). Bacterial biovolume and biomass estimations. Appl. environ. Microbiol. 49: 1488-1493

Bratbak, G., Dundas, 1. (1984). Bacterial dry matter content and biomass estimations. Appl environ. Microbiol. 48: $755-757$

Campbell, L., Carpenter, E. J. (1987). Characterization of phycoerythrin-containing Synechococcus spp populations by immunofluorescence. J. Plankton Res. 9: 1167-1181

Carpenter, E. J., Campbell, L. (1988). Diel patterns of cell division and growth rates of Synechococcus spp. in Long Island Sound. Mar. Ecol. Prog. Ser. 47: 179-183

Campbell, L., Carpenter, E. J., Iacono, V. J. (1983). Identification and enumeration of marine chroococcoid cyanobacteria by immunofluorescence. Appl. environ. Microbiol. 46: $553-559$

Cole, B. E., Cloern, J. E., Alpine, A. E. (1986). Biomass and productivity of three phytoplankton size classes in the San Francisco Bay. Estuaries 9: 117-126

Cuhel, R. L., Waterbury, J. B. (1984). Biochemical composition and short term nutrient incorporation patterns in a unicellular marine cyanobacteria Synechococcus (WH7803). Limnol. Oceanogr. 29: 370-374

El Hag, A. G. D., Fogg. G. E. (1986). The distribution of coccoid blue-green algae (Cyanobacteria) in the Menai Straits and the Irish Sea. Br. phycol. J. 21: 45-54

Eppley, R. W., Reid, F. M., Strickland, J. D. (1970). The ecology of the plankton off La Jolla, California in the period April through September, 1967 Part III. Estimates of phytoplankton crop size, growth rate, and primary production. Bull. Scripps Instn Oceanogr. 17: 33-42

Fisher, T. R., Harding, L. W., Stanley, D. W., Ward, L. G. (1988). Phytoplankton, nutrients and turbidity in the Chesapeake, Delaware and Hudson Estuaries. Estuar. coast. Shelf Sci. 27:61-93

Fumas, M. J. (1983). Community structure, biomass and productivity of size-fractionated summer phytoplankton populations in lower Narragansett Bay, Rhode Island. J, Plankton Res. 5: 637-655

Glover, H. E., Phinney, D. A., Yentsch, C. S. (1985a). Photosynthetic characteristics of picoplankton compared with those of larger phytoplankton populations, in various water masses in the Gulf of Maine. Biol. Oceanogr. 3: 223-248

Glover, H. E., Smith, A. E., Shapiro, L. (1985b). Diurnal variations in phytosynthetic rates: comparison of ultraphytoplankton with a larger phytoplankton size fraction. J. Plankton Res. 7: 519-535

Haas, L. W. (1975). Plankton dynamics in a temperate estuary with observations on a variable hydrographic conditions. Doctoral dissertation, School of Marine Science, College of William and Mary, Gloucester Point, Virginia

Haas, L. W. (1977). The effect of the spring-neap tidal cycle on the vertical salinity structure of the James, York and Rappahannock Rivers, Virginia, U.S.A. Estuar. coast. mar. Sci. 5: $485-496$

Haas, L. W. (1982). Improved epifluorescence microscopy for observing planktonic microorganisms. Annls Inst. océanogr., Paris 58: 940-946
Haas, L. W., Hastings, S. J., Webb, K. L. (1981). Phytoplankton response to a stratification-mixing cycle in the York River Estuary during late summer. In: Neilson, B. J., Cronin, L. E. (eds.) Estuaries and nutrients. Humana Press, Clifton, New Jersey, p. 619-636

Haas, L. W., Pearl, H. W. (1988). The roles of blue-green algae McCoy, S. E. (ed.) Chesapeake Bay. NOAA Estuary-ofthe-Month Seminar Series No. 5. National Oceanic and Atmospheric Administration, Estuarine Programs Office, Washington, D. C., p. 99-113

Harding, L. W., Meeson, B. W., Fisher, T. R. (1985). Photosynthesis patterns in Chesapeake Bay phytoplankton: shortand long-term responses of P-I curve parameters to light. Mar. Ecol. Prog. Ser. 26: 99-111

Hayward, D., Haas, L. W., Boon, J. D., Webb, K. L, Friedland, K. D. (1986). Empirical models of stratification variation in the York River Estuary, Virginia, USA. In: Bowman, J., Yentsch, M., Peterson, W. T. (eds.) Tidal mixing and plankton dynamics. Lecture notes on Coastal and Estuarine Studies, Vol. 17. Springer-Verlag, Berlin, p. 346-367

Hayward, D., Welch, C. S., Haas, L. W. (1982). York River destuatification: ân estuai y-subesiuary inieraction. Science 216: 1413-1414

Herbland, A., Le Bouteiller, A., Raimbault, P. (1985). Size structure of phytoplankton biomass in the equatorial Atlantic Ocean. Deep Sea Res. 32: 819-836

Iturriaga, R., Mitchell, B. G. (1986). Chroococcoid cyanobacteria: a significant component in the food web dynamics of the open ocean. Mar. Ecol. Prog. Ser. 28: 291-297

Jassby, A. D., Platt, T. (1976). Mathematical formulation of the relationship between photosynthesis and light for phytoplankton. Limnol. Oceanogr. 21: 540-547

Jeffrey, S. W., Humphrey, G. F. (1975). New spectrophotometric equations for determining chlorophylls $a_{1} b, c_{1}$ and $c_{2}$ in higher plants, algae and natural phytoplankton. Biochem. Physiol. Pfl. 167: 191-194

Jochem, F. (1988). On the distribution and importance of picocyanobacteria in a boreal inshore area (Kiel Bight, Western Baltic). J. Plankton Res. 10; 1009-1022

Johnson, P. W., Sieburth, J. M. (1979). Chroococcoid cyanobacteria in the sea: a ubiquitous and diverse phototrophic biomass. Limnol. Oceanogr. 24: 928-936

Johnson, P. W., Sieburth, J. M. (1982). In-situ morphology and occurrence of eucaryotic phototrophs of bacterial size in the picoplankton of estuarine and oceanic waters. J. Phycol. 18: 318-327

Kana, T. M., Glibert, P. M. (1987). Effects of irradiances up to $2000 \mu \mathrm{E} \mathrm{m}^{-2} \mathrm{sec}^{-1}$ on marine Synechococcus WH7803: I Growth, pigmentation and cellular composition. Deep Sea Res. 34: 479-495

Krempin, D. W., Sullivan, C. W (1981). The seasonal abun dance, vertical distribution, and relative microbial biomass of chroococcoid cyanobacteria at a station in southern California coastal waters. Can. J. Microbiol. 27: 1341-1344

Kuosa, H. (1988). Occurrence of autotrophic picoplankton along an open sea-inner archipelago gradient in the Guif of Finland, Baltic Sea. Ophelia 28: 85-93

Lee, S., Fuhrman, J. A. (1987). Relationships between biovolume and biomass of naturally derived marine bacterioplankton. Appl. environ. Microbiol. 53: 1298-1303

Li, W K. (1986). Experimental approaches to field measurements: methods and interpretation. In: Platt, T., Li, W K (eds.) Photosynthetic picoplankton, Can. J. Fish. Aquat. Sci. Department of Fisheries and Oceans, Ottawa, p. 251-286

Li, W K., Subba Rao, D. V., Harrison, W. G., Smith, J. C., Cullen, J. J., Irwin, B., Platt, T (1983). Autotrophic picoplankton in the tropical ocean. Science 219: 292-295 
Malone, T. C. (1980). Algal size: In: Morris, I. (ed.) The physiological ecology of phytoplankton. Studies in ecology, Vol. 7. University of California Press. Berkeley, p. $433-463$

Malone, T. C., Kemp, W. M., Ducklow, H. W., Boynton, W. R., Tuttle, J. H., Jonas, R. B. (1986). Lateral variation in the production and fate of phytoplankton in a partially stratified estuary. Mar Ecol. Prog. Ser. 32: 149-160

Marshall, H. G., Lacouture, R. (1986). Seasonal patterns of growth and composition of phytoplankton in the lower Chesapeake Bay and vicinity. Estuar. coast. Shelf Sci. 23: $115-130$

McCarthy, J. J., Taylor, W. R., Loftus, M. E. (1974). Significance of nanoplankton in the Chesapeake Bay Estuary and problems associated with the measurement of nanoplankton productivity. Mar. Biol. 24: 7-16

McManus, G. B., Fuhrman, J. A. (1988). Clearance of bacteriasized particles by natural populations of nanoplankton in the Chesapeake Bay outflow plume. Mar. Ecol. Prog. Ser. 42: 199-206

Murphy, L. S., Haugen, E. M. (1985). The distribution and abundance of phototrophic ultraplankton in the North Atlantic. Limnol. Oceanogr. 30: 47-58

NOAA Tide Tables (1985). High and low water predictions. East Coast of North and South America including Greenland. U.S. Department of Commerce, National Oceanic and Atmospheric Administration, National Ocean Service. Issued 1984

Patten, B. C., Mulford, R. A., Warinner, J. E. (1963). An annual phytoplankton cycle in the lower Chesapeake Bay. Chesapeake Sci. 4: 1-20

Perkins, F. O., Haas, L. W., Phillips, D. E., Webb, K. L. (1981). Ultrastructure of a marine Synechococcus possessing spinae. Can. J. Microbiol. 27: 318-329

Platt, T., Li, W. K. (1986). Photosynthetic picoplankton. Can. J. Fish. Aquat. Sci. 214

Platt, T., Subba Rao, D. V., Irwin, B. (1983). Photosynthesis of picoplankton in the sea. Nature, Lond. 301: 702-704

Putt, M., Prézelin, B. B. (1985). Observations of diel patterns of photosynthesis in cyanobacteria and nannoplankton in the Santa Barbara Channel during 'el Niño'. J. Plankton Res. 7: 779-790

Sellner, K. G. (1983). Plankton productivity and biomass in a tributary of the upper Chesapeake Bay. I Importance of size-fractionated phytoplankton productivity, biomass and species composition in carbon export. Estuar. coast. Shelf Sci. 17: 197-206

Shapiro, L. P., Haugen, E. M. (1988). Seasonal distribution and

This article was presented by Dr S. Y. Newell, Sapelo Island, Georgia, USA temperature tolerance of Synechococcus in Boothbay Harbor, Maine. Estuar. coast. Shelf Sci. 26: 517-525

Sieburth, J. McN. (1984). Protozoan bacterivory in pelagic waters. In: Hobbie, J. E., Williams, P. J. LeB. (eds.) Heterotrophic activity in the sea. Plenum Press, New York, p. $405-444$

Sournia, A. (ed.) (1978). Phytoplankton manual. Monographs on oceanographic methodology, Vol. 6 . United Nations Educational, Scientific and Cultural Organization, p. $236-237,273-279$

Taguchi, S. (1976). Relationship between photosynthesis and cell size of marine diatoms. J. Phycol. 12: 185-189

Takahashi, M., Bienfang, P. K. (1983). Size structure of phytoplankton biomass and photosynthesis in subtropical Hawailan waters. Mar. Biol. 76: 203-211

Takahashi, M., Kikuchi, K., Hara, Y (1985). Importance of picocyanobacteria biomass (unicellular, blue-green algae) in the phytoplankton population of the coastal waters off Japan. Mar. Biol. 89: 63-69

Thomsen, H. A. (1986). A survey of the smallest eucaryotic organisms of the marine phytoplankton. In: Platt, T., Li, W. K. (eds.) Photosynthetic picoplankton. Can. J. Fish. Aquat. Sci., Department of Fisheries and Oceans, Ottawa, p. $121-158$

Van Valkenberg, S. D., Flemer, D. A. (1974). The distribution and productivity of nannoplankton in a temperate estuarine area. Estuar. coast. Mar. Sci. 2: 311-322

Waterbury, J. B., Watson, S. W., Guillard, R. R., Brand, L. E. (1979). Widespread occurrence of a unicellular marine, planktonic, cyanobacterium. Nature, Lond. 277: 293-294

Waterbury, J. B., Watson, S. W., Valois, F. W., Franks, D. G. (1986). Biological and ecological characterization of the marine unicellular cyanobacterium Synechococcus. In: Platt, T., Li, W. K. (eds.) Photosynthetic picoplankton. Can. J. Fish. Aquat. Sci., Department of Fisheries and Oceans, Ottawa, p. 71-120

Watson, S. W., Novitsky, T. J., Quinby, H. L., Valois, F. W. (1977). Determination of bacterial number and biomass in the marine environment. Appl. environ. Microbiol. 33: 940-946

Wojcik, F. J. (1981). Data Report 17: Monthly salinity data for the York River plotted by river mile by month. September 1981. Virginia Institute of Marine Science, Gloucester Point, Virginia

Wood, A. M., Moran, P. K., Muirhead, K., Phinney, D. A., Yentsch, C. M., Waterbury, J. B. (1985). Discrimination between types of pigments in marine Synechococcus spp. by scanning spectroscopy, epifluorescence microscopy, and flow cytometry. Limnol. Oceanogr. 30: 1303-1315

Manuscript received: July 27, 1988

Revised version accepted: December 12, 1988 